\title{
German opposition may delay Framework
}

Brussels. The European Communities (EC)'s next five-year Framework research programme, scheduled to start in 1994, may be delayed for more than a year because of Germany's wish to see a significant cut in the European Commission's proposed research budget of ECU13.1 billion (US\$15 million).

Elections to the European Parliament will be held next June. As a result, the EC has only a short window in which to complete the complex approval procedure for its fourth Framework programme. To meet the necessary deadlines, the council of research ministers must approve the budget unanimously at its next meeting in December.

If Germany, which is said to be seeking a figure as low as ECU8 billion, does not budge, the council will be forced to approve a large reduction in the budget. And if that happens, the European Parliament is likely to use the right of veto it was given by the Maastricht agreement, which comes into force at the beginning of November. The whole approval process would then have to be rerun in 1995.

Both France and the United Kingdom also challenge the size of the budget. But there is confidence in Brussels that both will be prepared to accept changes in the content of the Framework programme, and perhaps a slight reduction in the budget, rather than risk a delay.

Belgium, in its role as current president of the Council of Ministers, is trying to find a compromise between the Commission, the Parliament and the Council. One possibility being considered would be to freeze about ECU1 billion of the budget.

Germany's science minister, Paul Kruger, is said to be keen to reach agreement with his colleagues. But the finance minister, Theo Waigel, may not let him. The cost of reunification has forced Germany to cut its domestic spending on science, making it politically difficult to agree to the proposed ECU6.2 billion increase in funding for Frame-

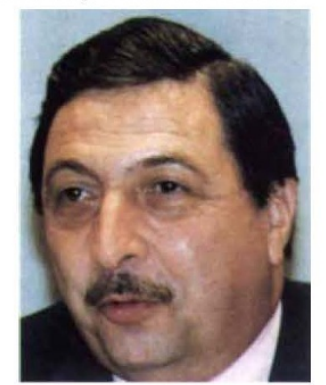

Desama: defends joint research spending. work over the next five years.

Indeed, all three of the EC's three largest paymasters are reluctant to fund research controlled by Brussels when they are having to reduce spending on domestic research which they control directly. This reluctance is further fuelled by the continuing belief that the quality of many joint research projects is lower than that in their own national programmes.

Claude Desama, the president of the Parliament's energy, research and technology committee, says he is "cautious" about the proposal to freeze part of the Framework budget. He argues that the increase in the budget being sought by the Parliament is not as large as it appears, as much of it covers the transfer of other EC research projects into Framework under the Maastricht Treaty.

Desama admits that a reduction in the budget request might allow Germany to save face at home. But he says that it would not save money, as any savings on research would be redeployed to other EC activities, such as regional development.

Fusion research could be one victim of any large reduction of the Framework budget. Funding for fusion has been almost doubled in the proposed programme, to ECU980 million. One parliament official says that for the first time many people are "thinking the unthinkable", namely abandoning the premium being paid to increase the chances of the International Thermonuclear Experimental Reactor being built in Europe.

The cost of the fusion programme was expected to go unquestioned until the end of the decade. But if the Framework budget is pruned, there will be pressure "to take it out of the shopping basket, and buy other goodies", he says.

Declan Butler

\section{'Precompetitive' research heads for the history books}

Brussels. Pressure is mounting on the European Communities (EC) to abandon the rule specifying that research they support must be "precompetitive", that is, far enough from the market to let companies collaborate without giving away trade secrets.

The rule was introduced by Etienne Davignon, then research and industry commissioner, in 1984. His goal was to stimulate both industrial recovery and the single market by encouraging national champions to work together. Cooperation in research became the means of achieving this goal; and 'precompetitive' research was seen as a solution to the reluctance of industrial competitors to collaborate.

But Davignon, speaking at the European Science Summit organized by the European Parliament in Brussels earlier this month, suggested that the time has come to rethink the relevance of the rule to $E C$ research. The policies he introduced may have encouraged European companies to merge into larger multinationals; but industrial and economic needs have changed.

The failure of EC research to close the technology gap with the United States and Japan has once again prompted a reflection on how, if at all, public money should be used to promote innovation. Simultaneously, the Maastricht agreement has extended the goals of EC-funded research from merely "strengthening the scientific and technological basis of European industry" to promoting cooperation on virtually any research considered valuable to Europe.

One result is likely to be the disappearance of the term 'precompetitive'. "It's time to whip away the precompetitive figleaf", says a staff member of the Parliament's energy, research and technology committee.

If the research is first class, companies will want to do it on their own, he says. Most precompetitive research projects would never be done by companies if the EC was not paying half of the costs.

Many now feel that the notion of precompetitive research is based on an obsolete, linear model of innovation. In contrast, the European Parliament, among others, also wants EC funding to be reformulated on the basis of a 'systems' model of the innovation process.

For example, members of parliament say the EC would get more for its money in terms of boosting competitivity by increasing support for both fundamental research and technology transfer. The European Com- mission has already proposed increasing funding for technology transfer in the fourth Framework programme to ECU600 million - more than 5 per cent of the total. But many want it to spend much more.

Rolf Linkohr, rapporteur of the parliamentary committee, has also proposed that the EC puts more money into funding contract research organizations to disseminate and develop the results of the research programmes it finances.

A more controversial suggestion is that the EC should also fund applied research on the basis of its technological merit, irrespective of its distance from the market. But any such move would raise fears among freemarketeers that the research funds might become used to prop up flagging European companies.

In a report last month to François Fillon, the French minister of higher education and research, Jean-Pierre Chevillot, the vicepresident of the French Conseil de la Recherche et de la Technologie, proposed that the EC should stop supporting precompetitive research and target its funding towards "partnerships" between public laboratories and private companies instead.

Declan Butler 